\title{
Population Race Structure of Pyrenophora tritici-repentis Prevalent on Wheat and Noncereal Grasses in the Great Plains
}

\author{
Shaukat Ali and Leonard J. Francl, Department of Plant Pathology, North Dakota State University, Fargo, ND \\ 58105
}

\begin{abstract}
Ali, S., and Francl, L. J. 2003. Population race structure of Pyrenophora tritici-repentis prevalent on wheat and noncereal grasses in the Great Plains. Plant Dis. 87:418-422.

The fungus Pyrenophora tritici-repentis, cause of tan spot of wheat, is an important foliar pathogen worldwide. Genetic variation in the fungal population prevalent in the Great Plains was studied by analysis of 270 single-spore isolates of $P$. tritici-repentis recovered from wheat, durum, and 10 noncereal grasses: Alti wild rye, barnyard grass, crested wheatgrass, intermediate wheatgrass, needle and thread grass, quackgrass, smooth bromegrass, sand reedgrass, slender wheatgrass, and wild barley. The isolates were grouped into five known races based on necrosis and/or chlorosis induction on standard differentials with two additional wheat genotypes ND495 and M-3. The isolates recovered from wheat were races 1, 2, and 4, while those from durum were races 1 and 5. Isolates from noncereal grasses were all race 4, except for the recovery of two isolates of race 1 from smooth bromegrass. Race 3 was not found in this study. This is the first record of barnyard grass and slender wheatgrass as alternative hosts for $P$. tritici-repentis. The recovery from noncereal grasses suggests that the fungus has a fairly wide host range; however, predominance of a race that is avirulent on wheat on these grasses tends to eliminate their significance in the disease epidemiology of wheat. The results indicate that $P$. tritici-repentis has a diverse population on wheat and noncereal grasses. For durable resistance, wheat lines should be tested against all virulent races found in the field.
\end{abstract}

The fungus Pyrenophora tritici-repentis (Died.) Drechs., anamorph Drechslera tritici-repentis (Died.) Shoemaker (synonym Helminthosporium tritici-repentis Died.), causes tan spot, a foliar disease of wheat worldwide (18). The fungus produces lens-shaped necrotic lesions with a chlorotic halo on susceptible cultivars. The fungus is also pathogenic on many other members of the family Poae $(11,18,24)$. The fungal isolates from wheat are crosspathogenic on grasses and vice versa $(18,20,22,23)$. The pathogen can over-season on diseased seed, infested crop residue, and overwintering grass hosts (11). Since the 1970s, the disease has become a serious problem and sporadically caused considerable losses (3 to 50\%) in production in major wheat growing areas in the United States and elsewhere $(18,31)$. The change in disease severity could be due to a change in pathogen virulence, wide adoption of no-till and conservation tillage practices, and/or introduction of susceptible cultivars.

In attempting to develop durable and resistant cultivars to combat plant diseases,

Corresponding author: Shaukat Ali

E-mail: shaukat.ali@ndsu.nodak.edu

Accepted for publication 22 November 2002.

Publication no. D-2003-0214-04R

(C) 2003 The American Phytopathological Society knowledge of the genetic diversity of plant pathogens is essential. The $P$. triticirepentis population on wheat and alternative hosts shows variability in both virulence and aggressiveness $(1,10,16,20,22$, $23,27,29,32,33)$. The fungal populations prevalent on durum were not included in these aforementioned studies. In most cases, virulence and/or aggressiveness was measured using a quantitative rating scale based on lesion size and/or necrotic leaf area. For example, 40 isolates collected from the United States and Canada were tested for their virulence on five spring wheat genotypes, one durum genotype, and one barley genotype (10). These isolates were grouped into 12 races, based on leaf area infected and lesion number produced per $\mathrm{cm}^{2}$. Krupinsky (24) recovered 87 single-spore isolates of $P$. tritici-repentis from various grass species and barley and tested them on wheat. Isolates were statistically different in their aggressiveness as they induced variable necrotic lesion sizes. This indicated that other grass hosts could provide a potential reservoir for genetic variation in the pathogen population.

Two qualitative types of symptoms, tan necrosis (nec+) and extensive chlorosis (chl+) produced by $P$. tritici-repentis on susceptible wheat genotypes, were identified by Lamari and Bernier (26). P. triticirepentis isolates have been grouped into five races based on their ability to induce necrosis and chlorosis (race 1), necrosis only (race 2), chlorosis only (races 3 and 5 both produce chlorosis, but on different genotypes), and lack of either necrosis or chlorosis (race 4) on appropriate wheat genotypes $(26,28)$. Three host-selective toxins, Ptr ToxA, Ptr ToxB, and Ptr ToxC, have been isolated to date $(7,9,11,30)$. These toxins are associated with typical tan spot symptoms, tan necrosis (ToxA) and chlorosis (ToxB and ToxC), on susceptible wheat cultivars. After the discovery of the three host-selective toxins and the demonstration of independent genetic mechanisms behind the interaction of hexaploid/tetraploid wheats and $P$. tritici-repentis races 1,3 , and $5(14,15)$, the race classification system seems reliable for studying genetics of the fungal population.

In 1989, Lamari and Bernier (26) reported that a majority of isolates collected in western Canada grouped as race 1; however, in 1998, both races 1 and 2 were prevalent in the region (27). In another study, 59 isolates were obtained from wheat samples collected from nine counties of South Dakota and tested by inoculating them individually on wheat lines Celtic (susceptible to necrosis and chlorosis) and Erik (resistant) (1). Sixty-four percent of the isolates produced necrosis and chlorosis (i.e., race 1 ), and $12 \%$ produced chlorosis. Only $2 \%$ caused necrosis only, and the rest of the isolates produced small lesions without necrosis or chlorosis. The fungal population on durum has not been explored yet in North America.

It was hypothesized that the $P$. triticirepentis populations prevalent on noncereal grasses in wheat cultivated areas, grasslands, state parks, and national parks in the northern Great Plains might differ from one another. The grasses prevalent in locations remote from wheat have only a small chance to be exposed to the pathogen population that exists on wheat and may represent an independent genetic reservoir with unique virulence profiles. The objective of this study was to characterize the $P$. triticirepentis populations prevalent on durum, wheat, and noncereal grasses in the U.S. Great Plains. Results have been reported in brief $(2-4,6)$.

\section{MATERIALS AND METHODS}

Pyrenophora tritici-repentis isolates. Diseased leaf samples were collected from spring wheat $(\mathrm{n}=10$ samples from different locations), durum ( $\mathrm{n}=25)$, and 28 noncereal grass host species $(\mathrm{n}=118)$, and processed for the recovery of $P$. tritici- 
repentis. The durum leaf samples were collected from 15 locations within the primary durum production area of northeastern North Dakota on 24 and 25 July 1997. The noncereal grass host species samples were taken from North Dakota, Minnesota, Montana, South Dakota, and Wyoming. The grass samples were collected from wheat areas $(n=66)$, national grasslands $(\mathrm{n}=30)$, and state and national parks $(n=22)$. These samples were collected in the second week of July 1998. The noncereal grass host species sampled and number of samples of each species are listed in Table 1.

To recover $P$. tritici-repentis from the samples, leaves of each sample were cut into 2-cm lengths, and 50 leaf pieces were plated, 10 per plate, in plastic petri dishes ( $9 \mathrm{~cm}$ diameter) containing three layers of dampened Whatman no. 1 filter paper. To dampen the filter papers, $3 \mathrm{ml}$ of distilled sterilized water was added to each plate. The leaves were incubated in an alternating cycle of $24 \mathrm{~h} \mathrm{light}$ at $22^{\circ} \mathrm{C}$ and $24 \mathrm{~h}$ in dark at $16^{\circ} \mathrm{C}$ for $96 \mathrm{~h}$ to induce conidiophore and conidia formation. Incubated leaf pieces were examined under a stereoscope, and conidia of the fungus were picked individually with a flamed steel needle that had been cooled in a plate of V8PDA ( 150 $\mathrm{ml}$ of $\mathrm{V} 8$ juice, $10 \mathrm{~g}$ of Difco potato dextrose agar, $3 \mathrm{~g}$ of $\mathrm{CaCo}_{3}, 10 \mathrm{~g}$ of Bacto agar, and $850 \mathrm{ml}$ of distilled water) (26). This procedure produces a sticky needle tip for picking of a single conidium. Each conidium was transferred onto an individual V8PDA plate. The single-spore cultures were incubated at $21^{\circ} \mathrm{C}$ in the dark for 8 days or until the colony size reached about $7 \mathrm{~cm}$ in diameter.

Twenty-five isolates of $P$. tritici-repentis were obtained from wheat, 71 from durum, and 77 from alternative hosts. Additionally, 51 isolates collected from North Dakota, 9 from South Dakota, 10 from Kansas, 12 from Oklahoma isolated from wheat, and 15 isolates obtained from other grass hosts (bromegrass [ $\mathrm{n}=7]$, western wheatgrass [n $=5]$, and wild barley [ $n=3$ ] collected from northern Great Plains) were included in this study. The isolates from Kansas, Oklahoma, and 16 of 51 from North Dakota were recovered in late 1980s and were also included in the analysis of race structure. All isolates were stored until testing following the protocol developed by Jordahl and Francl (19).

Inoculum production. To produce inoculum, four colonies of each isolate of stored cultures were initiated on V8PDA. The plates were incubated at $21^{\circ} \mathrm{C}$ in darkness until the colonies were about $5 \mathrm{~cm}$ in diameter. The plates were then flooded with sterilized distilled water, and the mycelium was matted with a flamed test tube. Excess water was decanted, and plates were incubated in an alternating cycle of $24 \mathrm{~h}$ light at $22^{\circ} \mathrm{C}$ and $24 \mathrm{~h}$ dark at $16^{\circ} \mathrm{C}$ to induce the formation of conidiophores and conidia. When conidia were formed, $30 \mathrm{ml}$ of sterilized distilled water were added to each dish and conidia were dislodged using a looped wire. The conidial suspension was adjusted to 3,000 per $\mathrm{ml}$ following the procedure described by Jordahl and Francl (19). Tween 20 was added at one drop per $100 \mathrm{ml}$ of spore suspension before inoculations to enhance adhesion.

Inoculations and characterization of the isolates. The 270 isolates were grouped into races by inoculating them individually on seedlings of wheat differentials (26) at the two-leaf stage. Two additional genotypes, ND495 (susceptible to tan spot) and M-3 (resistant), were added to the standard set of differentials to increase the chance of finding more variants in the fungal population. Seeds were planted in plastic cones $(3.8 \mathrm{~cm}$ in diameter and $20 \mathrm{~cm}$ in length) containing Sunshine Mix no. 1 (Fison Horticulture, Vancouver, B.C.) and grown in the greenhouse at an average temperature of $21^{\circ} \mathrm{C}$ (20 to $23^{\circ} \mathrm{C}$ ) with a 16 -h photoperiod. Seven seedlings of each differential genotype were inoculated individually with a spore suspension, 3,000 spores per $\mathrm{ml}$, of each isolate until runoff. Inoculated seedlings were air-dried, moved to a mist chamber at $18^{\circ} \mathrm{C}$ for $24 \mathrm{~h}$, and then transferred to a growth chamber at $21^{\circ} \mathrm{C}$ with 16-h photoperiod for 7 days. The seedlings were rated for symptom development using a qualitative rating scale (Table 2) (26). The isolates were grouped into the appropriate races based on lesion type, tan necrosis and chlorosis, and absence of both lesion types.

\section{RESULTS}

Recovery of $P$. tritici-repentis from the samples. $P$. tritici-repentis was recovered from $40 \%$ of 153 samples. All wheat $(n=$ $10)$ and durum $(\mathrm{n}=25)$ samples were infected with $P$. tritici-repentis; whereas only $22 \%(26 / 118)$ of noncereal grass samples produced the fungus (Table 1). Only $20 \%$ $(6 / 30)$ of the smooth bromegrass samples produced $P$. tritici-repentis, with the rest of the samples infected with $P$. bromi (data not reported). Of the intermediate wheatgrass samples, $31 \%(5 / 16)$ produced the fungus, and $P$. tritici-repentis could be recovered from $14 \%(1 / 7)$ of the intermediate wheatgrass samples from wheat areas.

Table 1. Numbers of samples of noncereal grass species from which Pyrenophora tritici-repentis were recovered from wheat production areas, the Theodore Roosevelt National Grasslands, and several state and national parks

\begin{tabular}{|c|c|c|c|c|}
\hline \multirow[b]{2}{*}{ Common name } & \multirow[b]{2}{*}{ Scientific name } & \multicolumn{3}{|c|}{$\begin{array}{c}\text { Numbers } \\
\text { (P. tritici-repentis/total) }\end{array}$} \\
\hline & & Wheat & Grasslands & Parks \\
\hline Alti wild-rye ${ }^{a}$ & Leymus angustus (Trin). Pilg. & $3 / 6$ & $0 / 1$ & \\
\hline Barnyard grass & Echinochloa crusgalli (L.) Beauv. & $1 / 2$ & $0 / 1$ & $0 / 2$ \\
\hline Basin wild-rye ${ }^{a}$ & $\begin{array}{l}\text { Leymus cinereus } \\
\text { (Scribn. \& Merr.) A. Love }\end{array}$ & $0 / 1$ & & \\
\hline Big blue stem ${ }^{a}$ & Andropogon geradii Vitm. & $0 / 6$ & & \\
\hline Canada wild-rye ${ }^{a}$ & Leymus canadensis $\mathrm{L}$. & $0 / 1$ & & \\
\hline Crested wheatgrass ${ }^{\mathrm{a}}$ & Agropyron cristatum (L.) Gaertn. & $1 / 1$ & $0 / 3$ & \\
\hline Fowl manna grass & Glyceria striata (Lam.) Hitche & & & $0 / 2$ \\
\hline Green foxtail ${ }^{\mathrm{a}}$ & Setaria viridid (L.) Beauv. & $0 / 5$ & & $0 / 1$ \\
\hline Green needle grass ${ }^{\mathrm{a}}$ & Stipa viridula Trin. & $0 / 2$ & & \\
\hline Indian grass ${ }^{\mathrm{a}}$ & Sorghastrum nutand (L.) Nash & $0 / 2$ & & \\
\hline $\begin{array}{l}\text { Intermediate } \\
\text { wheatgrass }^{\mathrm{a}}\end{array}$ & $\begin{array}{l}\text { Thinopyrum intermedium } \\
\text { (Host) Barkw. \& D. R. Dewey }\end{array}$ & $1 / 7$ & $1 / 4$ & $3 / 5$ \\
\hline June grass ${ }^{\mathrm{a}}$ & Koeleria cristata (L.) Pers. & $0 / 1$ & $0 / 1$ & \\
\hline Meadow foxtail ${ }^{\mathrm{a}}$ & Alopecurus paratensis $\mathrm{L}$. & & & $0 / 1$ \\
\hline $\begin{array}{l}\text { Needle-and-thread } \\
\text { grass }^{\mathrm{a}}\end{array}$ & Stipa comata Trin. \& Rupr. & $1 / 1$ & & \\
\hline Ouack grass ${ }^{\mathrm{a}}$ & Agropyron repens (L.) Beauv. & $1 / 3$ & $0 / 1$ & \\
\hline Reed Canary grass ${ }^{\mathrm{a}}$ & Phalaris arundinacea $\mathrm{L}$. & $0 / 1$ & & \\
\hline Russian wild-rye $^{a}$ & Psathyrostachys juncea (Fisch.) Nevski & $0 / 2$ & $0 / 2$ & \\
\hline Sand reed grass ${ }^{\mathrm{a}}$ & Calamovifta longifolia (Hook.) Scribn. & & $1 / 1$ & \\
\hline Slender wheatgrass & Elymus trachycaulum (Link) Malte & $1 / 2$ & $2 / 4$ & \\
\hline Slender wood grass & Cinna latifolia (Trev.) Griseb. & & & $0 / 1$ \\
\hline Smooth bromegrass ${ }^{\mathrm{a}}$ & Bromus inermis Leyss. & $1 / 11$ & $4 / 10$ & $1 / 9$ \\
\hline $\begin{array}{l}\text { Standard crested } \\
\text { wheatgrass }\end{array}$ & $\begin{array}{l}\text { Agropyron desertorum } \\
\text { (Fisch. Ex Link) Schult. }\end{array}$ & & $0 / 1$ & \\
\hline Switch grass ${ }^{\mathrm{a}}$ & Penicum virgatum $\mathrm{L}$. & $0 / 3$ & & \\
\hline Tall wheatgrass ${ }^{\mathrm{a}}$ & $\begin{array}{l}\text { Thinopyrum ponticum } \\
\text { (Podp.) Barkw. \& D. R. Dewey }\end{array}$ & $0 / 1$ & & \\
\hline $\begin{array}{l}\text { Thickspike } \\
\text { wheatgrass }^{\mathrm{a}}\end{array}$ & $\begin{array}{l}\text { Elymus lanceolatus } \\
\text { (Scribn. \& Smith) Gould }\end{array}$ & $0 / 2$ & & \\
\hline Timothy & Phleum pratense $\mathrm{L}$. & & & $0 / 1$ \\
\hline Western wheatgrass ${ }^{\mathrm{a}}$ & Agropyron smithii & $0 / 2$ & & \\
\hline Wild barley ${ }^{\mathrm{a}}$ & Critesion jubatum (L.) Nevski & $3 / 3$ & $1 / 1$ & \\
\hline Wild oat & Danthonia intermedia Vasey & $0 / 1$ & & \\
\hline Total samples & & $13 / 66$ & $9 / 30$ & $4 / 22$ \\
\hline
\end{tabular}

a Previously reported as host (Hosford [17]; Krupinsky [20,24]). 
In contrast, $44 \%(4 / 9)$ of the intermediate wheatgrass samples from parklands and grasslands were infected with the fungus. During this study, Drechslera gigantea, D. dactylidis, Septoria spp., and Ascochyta spp. were also observed on various sam-

$P$. tritici-repentis races. Races 1,2 , and 4 on wheat, 1 and 5 on durum, and 1 and 4 on noncereal grasses were identified (Table 3). The majority of the isolates on wheat and durum were typed as race 1 (Table 3 ). Of 107 isolates from wheat in the northern Great Plains, only $3 \%$ of the fungal population was grouped as race 2 . Five percent of the isolates did not produce any symptom and were grouped under race 4 . In contrast to the fungal population on wheat and durum, almost all (90/92) of the isolates obtained from noncereal grasses were grouped as race 4, regardless of the area from which the sample was collected (Table 3 ). Race 3 and off-type races were not found in this study.

\section{DISCUSSION}

The recovery data for $P$. tritici-repentis indicate that species of alternative hosts can harbor the fungus regardless of location or habitat where they exist and that the fungus has a fairly wide host range. The results are in agreement with previous studies that showed the fungus could survive on, and be isolated from, field samples of various noncereal grasses $(12,21,22,24)$. In this study, $P$. triticirepentis was recovered from two noncereals, barnyard grass and slender wheat grass, which had not been previously reported as hosts (24). In addition, 8 of the ples (data not recorded).

23 grass species previously reported as alternative hosts (24) produced the fungus (Table 1).

Smooth bromegrass use as a pasture grass and its widespread natural population in the Great Plains make this grass a potential overwintering source of $P$. triticirepentis and a potential source of physiological variation in the fungal population. In a previous study, smooth bromegrass was found to be nearly equal in susceptibility to the fungus as wheat (20). In one study, $73 \%$ of the field samples collected during 1981 to 1983 produced $P$. triticirepentis (21). However, in the present study, $P$. tritici-repentis was recovered from only $20 \%$ of the samples, with $P$. bromi recovered from the rest. The results confirm previous studies $(20,21)$ that the fungus could survive and be recovered from smooth bromegrass field samples.

P. bromi, which causes brown leaf spot of smooth bromegrass, and $P$. triticirepentis are morphologically very similar (34). P. bromi can be misidentified as $P$. tritici-repentis when isolated from smooth bromegrass. Krupinsky (21) reported that the samples collected in 1984 produced more P. bromi isolates than those collected during 1981 to 1983 . In this study, $80 \%$ of the smooth bromegrass samples produced P. bromi.

A higher recovery rate of $P$. bromi isolates from the smooth bromegrass samples may be expected, as the majority of the smooth bromegrass wild population and all commercial cultivars are susceptible to this pathogen (8). P. tritici-repentis may not compete well with $P$. bromi on this host under field conditions. In addition, a low

Table 2. Wheat differentials used in this study and their reaction to known races of Pyrenophora tritici-repentis

\begin{tabular}{llllllc}
\hline & \multicolumn{6}{c}{ Wheat differentials } \\
\cline { 2 - 7 } Race & Glenlea & ND495 & Katepwa & $\mathbf{6 B 3 6 5}$ & Salamouni & M-3 $^{\mathbf{a}}$ \\
\hline 1 & Necrosis & Necrosis & Necrosis & Chlorosis & Resistant & Resistant \\
2 & Necrosis & Necrosis & Necrosis & Resistant & Resistant & Resistant \\
3 & Resistant & Resistant & Resistant & Chlorosis & Resistant & Resistant \\
4 & Resistant & Resistant & Resistant & Resistant & Resistant & Resistant \\
5 & Resistant & Resistant & Chlorosis & Resistant & Resistant & Resistant \\
\hline
\end{tabular}

${ }^{a}$ A synthetic wheat also designated as W-7976.

Table 3. Proportion of isolates of Pyrenophora tritici-repentis, collected from wheat, durum, and noncereal grasses in the U.S. Great Plains, that typed as races indicated

\begin{tabular}{lcccccc}
\hline & & \multicolumn{5}{c}{${\text { Races }(\boldsymbol{\%})^{\mathbf{b}}}$} \\
\cline { 5 - 8 } Source & Isolates tested $^{\mathbf{a}}$ & $\mathbf{1}$ & $\mathbf{2}$ & $\mathbf{3}$ & $\mathbf{4}$ & $\mathbf{5}$ \\
\hline Bread wheat - Northern Great Plains $^{\mathrm{c}}$ & 85 & 92 & 3 & 0 & 5 & 0 \\
Bread wheat - Southern Great Plains $^{\mathrm{c}}$ & 22 & 96 & 0 & 0 & 5 & 0 \\
Durum & 71 & 89 & 0 & 0 & 0 & 11 \\
Noncereal grasses & 92 & 2 & 0 & 0 & 98 & 0 \\
\hline
\end{tabular}

${ }^{a}$ Isolates from durum and spring wheat in North Dakota were obtained on 24 and 25 July 1997; isolates from Oklahoma and Kansas were collected in the late 1980s. Isolates from South Dakota were obtained in 1995; isolates from noncereal grasses were obtained in July 1998.

${ }^{\mathrm{b}}$ P. tritici-repentis isolates were grouped into different races as described by Lamari and Bernier (25).

${ }^{\mathrm{c}}$ Northern Great Plains $=$ North Dakota and South Dakota; Southern Great Plains $=$ Kansas and Oklahoma. recovery $(20 \%)$ of $P$. tritici-repentis from the collected samples further strengthens the idea that smooth bromegrass may not be a good source for $P$. tritici-repentis survival under field conditions.

De Wolf et al. (11) suggested that smooth bromegrass should be included with the wheat differentials in order to differentiate race 4 from $P$. bromi if the fungal isolates need to be characterized into races. Otherwise, isolates may be grown on the differential medium "sucrose proline agar medium" as suggested by Shoemaker (34). In the present study, the samples were analyzed by placing them on three layers of dampened filter paper. This procedure decreases the chance of one species overgrowing another species, as only conidia develop during the incubation period. Also, single spores were transferred from the incubated leaves onto V8PDA, a medium that can discriminate between the two species based on their growth rate and the presence or absence of protothecia (5).

A high frequency of recovery of $P$. tritici-repentis was expected from intermediate wheatgrass samples collected from wheat areas because the fungal population prevalent on wheat is known to infect intermediate wheatgrass. In addition, $P$. tritici-repentis isolates from wheat were found to be equally virulent on noncereal grasses such as intermediate wheatgrass and smooth bromegrass (22). In one study, $44 \%$ of field-collected intermediate wheatgrass leaf samples produced $P$. triticirepentis (25), similar to the $31 \%$ found overall in this study. However, the majority (4/9) of the positive intermediate wheatgrass leaf samples were collected from parklands and grasslands.

P. tritici-repentis was recovered at a high frequency from Alti wild rye and wild barley (from 3 of 6 and 3 of 3 samples, respectively) collected from wheat areas (Table 1). These grasses exist as weeds in cultivated areas, ditches, and so on; however, since these isolates typed as race 4 (producing neither necrosis nor chlorosis), their epidemiological significance in tan spot on wheat is probably minimal.

Based on these results, noncereal grasses prevalent in wheat, grassland, and parkland areas varied in supporting the growth of $P$. tritici-repentis. There could be two reasons for this variation: first, the fungal population may not be aggressive on noncereal grasses; and second, these wild populations of noncereals may vary in reaction from susceptible to resistant. The natural populations of these grasses are not expected to be homogenous, as they are out crossing and responding to selection pressures. Moreover, no specific trend was observed in the fungal recovery from noncereal grasses based on areas from which the samples were collected. However, the low recovery of $P$. tritici-repentis from a small number of noncereal grasses indicates that most of these species support a minimal 
growth of the fungus. This finding and the $98 \%$ recovery of race 4 (avirulent on wheat) suggest these grasses may not have a significant role in tan spot epidemiology on wheat in the northern Great Plains. $P$. tritici-repentis races 1,2 , and 4 were observed on wheat in the northern Great Plains. All isolates from the southern Great Plains were race 1 except for one isolate of race 4 . These results indicate that race 1 is the most prevalent race in the U.S. Great Plains. These findings are in agreement with previous work $(1,26)$ in which race 1 was found as the predominant race in South Dakota and western Canada. Predominance of race 1 in these regions could be due to: (i) lack of selection pressure because the majority of the wheat cultivars are susceptible; (ii) the production of multiple host-specific toxins such as Ptr ToxA and ToxC by race 1 , which makes it more fit than the other races; and (iii) little chance to produce recombinants as the fungus is homothallic.

Race 2 of $P$. tritici-repentis was observed in a very low frequency $(3 \%)$ in the northern Great Plains. Similarly, race 2 was observed infrequently in previous studies conducted in South Dakota (1) and western Canada (26). In western Canada, an increase in the proportion of race 2 over the years $1990(9 \%)$ to $1994(50 \%)$ has been reported (27). This increase was thought to be due to susceptibility of most of the wheat cultivars to both races 1 and 2. Host susceptibility to both races would be expected to exert minimal selection pressure on each race, and thus might provide equal chances for their survival (27). In the present study, the fungal isolates analyzed were collected in the 1980s and 1990s and from four states of the Great Plains. If the increase in race 2 population over the period of 1990 to 1994 was because of susceptibility of the cultivars (27), this is not the case in the U.S. Great Plains, where a majority of the cultivars used are at least moderately susceptible to both races and are sensitive to Ptr ToxA (S. Ali, unpublished). There could be three reasons that race 2 is still present in low frequency in this region: (i) the fungus is homothallic, which decreases the chances of recombinants; (ii) the fungus is multi-cyclic so even if both races reproduced equally during the wheat season, race 1 conidia would remain the most abundant, as it is the most prevalent race in the region; and (iii) the conidia are airborne and can be dispersed over kilometer distances so that races would mix rather than maintain isolated pockets (13).

In this study, $5 \%$ of the isolates obtained from wheat were grouped as race 4 but the origin of race 4 on wheat is unknown. The race 4 population may be coming from other grass hosts, in which $98 \%$ of the isolates were race 4 . It is suspected that race 4 might be nonpersistent in wheat fields because it would not compete well with races virulent on wheat.

Eleven percent of the isolates obtained from durum were race 5 . However, race 5 was isolated from a sample collected from an experimental research station at Langdon, ND. It is not surprising to find variation in the fungal population in an area where many wheat genotypes with diverse genetic backgrounds are grown for breeding and yield trials. The existence of race 5 in the northern Great Plains warns that the fungal population should be periodically screened for physiological specialization, especially for increased frequency of race 5. In addition, wheat genotypes should be tested for their reaction to race 5 to establish possible sources of resistance should the need arise.

Ninety-eight percent of the isolates obtained from noncereal grass hosts were grouped as race 4 . This indicates that grass and wheat hosts carry completely different populations of $P$. tritici-repentis. These results contrast with all previous studies in which isolates from noncereal grass hosts were found to be pathogenic on wheat and vice versa $(18,20,21)$; this contrast is likely due to a difference in sampling locations. In the previous studies, most of the samples were collected from areas where wheat and noncereals were grown in close proximity, which provides ample opportunity for the fungus to disperse from wheat and grow as a saprophyte on other hosts. In contrast, nearly half of the samples in this study were collected from areas remote from wheat production.

\section{ACKNOWLEDGMENTS}

We thank Yue Jin, Robert Hunger, William Bockus, and Joseph Krupinsky for kindly providing fungal isolates.

\section{LITERATURE CITED}

1. Ali, S., and Buchenau, G. W. 1992. Incidence of toxin-producing pathotypes of Pyrenophora tritici-repentis in South Dakota. (Abstr.) Phytopathology 82:1159.

2. Ali, S., and Francl, L. J. 1998. Race structure of Pyrenophora tritici-repentis isolated from wheat and grasses in the US Great Plains. (Abstr.) Phytopathology 88:S114.

3. Ali, S., and Francl, L. J. 1999. Races of Pyrenophora tritici-repentis on durum in the northern Great Plains of the U.S. (Abstr.) Phytopathology 89:S2.

4. Ali, S., and Francl, L. J. 2000. Reaction of four alternate hosts to five races of Pyrenophora tritici-repentis and two host selective toxins. (Abstr.) Phytopathology 90:S2.

5. Ali, S., and Francl, L. J. 2001. A differential medium for discriminating between Drechslera bromi and D. tritici-repentis. (Abstr.) Phytopathology 91:S2.

6. Ali, S., Francl, L. J., and De Wolf, E. D. 1999. First report of Pyrenophora tritici-repentis race 5 from North America. Plant Dis. 83:591.

7. Ballance, G. M., Lamari, L., and Bernier, C. C. 1989. Purification and characterization of a host selective toxin from Pyrenophora triticirepentis. Physiol. Mol. Plant Pathol. 35:203213.

8. Berg, C. C., and Sherwood, R. T. 1994. Stability of resistance to leaf disease in or- chardgrass and smooth bromegrass. Crop Sci 34:1495-1498

9. Brown, D. A., and Hunger, R. M. 1993. Production of a chlorosis-inducing, host-specific, low-molecular weight toxin by isolates of Pyrenophora tritici-repentis, cause of tan spot of wheat. J. Phytopathol. 137:221-232.

10. da Luz, W. C., and Hosford, R. M. 1980. Twelve Pyrenophora trichostoma races for virulence to wheat in the Central Plains of North America. Phytopathology 70:11931196.

11. De Wolf, E. D., Effertz, R. J., Ali, S., and Francl, L. J. 1998. Vistas of tan spot research. Can. J. Plant Pathol. 20:349-444.

12. Drechsler, C. 1923. Some graminicolous species of Helminthosporium. Intern. J. Agric. Res. 24:614-670.

13. Francl, L. J. 1997. Local and mesoscale dispersal of Pyrenophora tritici-repentis conidia. Can. J. Plant Pathol. 19:247-255.

14. Gamba, F. M., and Lamari, L. 1998. Mendelian inheritance of resistance to tan spot (Pyrenophora tritici-repentis) in selected genotypes of durum wheat (Triticum turgidum). Can. J. Plant Pathol. 20:408-414

15. Gamba, F. M., Lamari, L., and Brûlé-Babel, A. 1998. Inheritance of race specific necrotic and chlorotic reactions induced by Pyrenophora tritici-repentis in hexaploid wheats. Can. J. Plant Pathol. 20:401-407.

16. Gilchrist, S. L., Fuentes, S. F., and. de L. De la Isla de Baur, M. 1984. Determinacion de funentes resistencia contra Helminthosporium tritici-repentis bajo conditione de campo e invenadero. Agrociencia 56:95-105.

17. Hosford, R. M. 1971. A form of Pyrenophora trichostoma pathogenic to wheat and other grasses. Phytopathology 61:28-32.

18. Hosford, R. M. 1982. Tan spot - developing knowledge 1902-1981, virulent races and wheat differentials, methodology, rating systems, other leaf diseases, literature. Pages 124 in: Tan Spot of Wheat and Related Diseases Workshop. R. M. Hosford, ed. North Dakota Agric. Exp. Stn., Fargo.

19. Jordahl, J. G., and Francl, L. J. 1992. Increase and storage of cultures of Pyrenophora triticirepentis. Page 109 in: Advances in Tan Spot Research. L. J. Francl, J. M. Krupinsky, and M. P. McMullen, eds. North Dakota Agric. Exp. Stn., Fargo.

20. Krupinsky, J. M. 1982. Observation of the host range of isolates of Pyrenophora trichostoma. Can. J. Plant Pathol. 4:42-46.

21. Krupinsky, J. M. 1986. Pyrenophora triticirepentis, P. bromi, and Leptosphaeria nodorum on Bromus inermis in the northern Great Plains. Plant Dis. 70:61-64.

22. Krupinsky, J. M. 1987. Pathogenicity on wheat of Pyrenophora tritici-repentis isolated from Bromus inermis. Phytopathology 77:760-765.

23. Krupinsky, J. M. 1992. Aggressiveness of isolates of Pyrenophora tritici-repentis obtained from wheat in the northern Great Plains. Plant Dis. 76:87-91.

24. Krupinsky, J. M. 1992. Grass hosts of Pyrenophora tritici-repentis. Plant Dis. 76:92-95.

25. Krupinsky, J. M., and, Berdahl, J. D. 1984. Evaluation of Agropyron intermedium for reactions to various leaf spot diseases. Plant Dis. 68:1089-1091

26. Lamari, L., and Bernier, C. C. 1989 . Virulence of isolates of Pyrenophora tritici-repentis on 11 wheat cultivars and cytology of the differential host reactions. Can. J. Plant Pathol. 11:284-290.

27. Lamari, L., Gilbert, J., and Tekauz, A. 1998. Race differentiation in Pyrenophora triticirepentis and survey of physiologic variation in western Canada. Can. J. Plant Pathol. 20:396-400. 
28. Lamari, L., Sayud, R., Boulif, S. M., and Bernier, C. C. 1995. Identification of a new race in Pyrenophora tritici-repentis: Implications for the current pathotype classification system. Can. J. Plant Pathol. 17:312-318.

29. Misra, A. P., and Singh, R. A. 1972. Pathogenic differences among three isolates of Helminthosporium tritici-repentis and the performance of wheat varieties against them. Indian Phytopathol. 25:350-353.
30. Orolaza, N. P., Lamari, L., and Ballance, G. M. 1995. Evidence of a host-specific chlorosis toxin from Pyrenophora tritici-repentis, the causal agent of tan spot of wheat. Phytopathology 85:1282-1287.

31. Rees, R. G., Platz, G. J., and Mayer, R. J. 1982. Yield losses in wheat from yellow spot: Comparison of estimates derived from single tillers and plots. Aust. J. Agric. Res. 33:899908 .
32. Sah, D. N., and Fehrmann, H. 1992. Virulence patterns of geographically differing isolates of Pyrenophora tritici-repentis and sources of resistance in wheat. Plant Dis. 76:712-716.

33. Schilder, A. M. C., and Bergstrom, G. C. 1990. Variation in virulence within the population of Pyrenophora tritici-repentis in New York. Phytopathology 80:84-90.

34. Shoemaker, R. A. 1962. Drechslera Ito. Can J. Bot. 40:809-836 